\title{
Barikan sebagai warisan kearifan lokal dan pemersatu keberagaman agama di Dusun Bororejo, Desa Dadaplangu, Kecamatan Ponggok, Kabupaten Blitar
}

\author{
Amelia Susanto Putri, Eggi Alvado Da Meisa, Fira Fajria, Isnaini Diah Masitoh, Latifa \\ Nur Rohmah, Okvani Umikasari, Deny Wahyu Apriadi*
}

\author{
Universitas Negeri Malang, Jl. Semarang No. 5 Malang, Jawa Timur, Indonesia \\ *Penulis korespondensi, Surel: deny.apriyadi.fis@um.ac.id
}

Paper received: 03-02-2021; revised: 15-02-2021; accepted: 28-02-2021

\begin{abstract}
Abstrak
Indonesia merupakan negara yang kaya akan berbagai macam suku, agama, budaya, bahasa, dan ras. Hal ini disebabkan oleh banyaknya pulau yang terdapat di Indonesia, dengan adanya keberanekaragaman tersebut membuat masyarakat dituntut untuk mengembangkan sikap toleransi antar-sesama. Toleransi dalam kehidupan keberagaman sangat diperlukan, terutama dalam pergaulan hidup antara umat beragama yang didasarkan pada setiap agama menjadi sebuah tanggung jawab bagi setiap pemeluknya dan memiliki bentuk ibadah (ritual), memiliki sebuah tata cara yang ditaklifkan (dibebankan). Objek dari penelitian ini adalah penanaman sikap toleransi antar umat beragama yang terdapat di Dusun Bororejo Desa Dadaplangu beserta makna yang terkandung dalam setiap elemen acara. Sedangkan subjek yang menjadi subjek adalah seluruh warga Dusun Bororejo. Untuk memperoleh data penelitian ini, peneliti menggunakan metode observasi, wawancara, dan dokumentasi. Dengan latarbelakang agama yang berbeda, serta penanaman sikap toleransi yang dilakukan antar setiap individunya menjadikan setiap warganya memahami mengenai makna dari sebuah perbedaan, yang menyadarkan bahwa negara Indonesia memiliki beberapa agama yang sudah diakui oleh pemerintah dan kita harus menghormati antar sesama agama.
\end{abstract}

Kata kunci: keberagaman; sikap; toleransi; perbedaan agama; Barikan; Desa Dadaplangu; Dusun Bororejo Blitar Jawa Timur.

\section{Pendahuluan}

Indonesia dikenal sebagai Negara yang masyarakatnya ramah, sopan dan santun. Hal ini terjadi bukan hanya terhadap wisatawan asing saja melainkan juga terhadap masyarakat lokalnya. Di sisi lain Indonesia juga memiliki perbedaan latar belakang agama, ras, suku, dan adat istiadat yang beragam. Salah satu faktor yang mempengaruhi terbentuknya keberagaman yaitu adanya perbedaan letak geografis wilayah yang membentuk suatu masyarakat dengan karakakteristik tertentu tergantung bagaiman proses difusi agama, ras, suku, dan kebudayaan itu dapat tersebar. Perbedaan yang ada pada masyarakat indonesia terbilang sangat kompleks yang mana dapat dilihat dari banyaknya persentase kepercayaan lokal serta agama resmi yang telah diakui di Indonesia yang terdiri dari agama Islam yang pemeluknya sebanyak 87,21\%, Protestan 6,04\%. Katolik 3,58\%. Hindu 1,83\%, Budha 1,03\%, serta berkeyakinan Animis sebanyak $0,31 \%$. (Syamsul, 2005). Banyaknya kepercayaan yang dianut masyarakat bisa saja menimbulkan berbagai spekulatif yang mengakibatkan terjadinya gesekan antara penganut agama mayoritas dengan minoritas.

Namun di berbagai wilayah tertentu, perbedaan-berbedaan yang ada di antara bukan dijadikan sebagai pemicu adannya perpecahan, melainkan menjadi salah satu faktor pemersatu untuk hidup rukun di antara keberagaman umat beragama yang terintegrasi oleh 
suatu pengikat di tiap-tiap wilayah yang dinamakan kearifan lokal. Masyarakat saling berinteraksi satu sama lain, saling membantu, dan hidup dalam keharmonisan serta saling menjaga kearifan lokal yang telah ada sejak turun temurun. Kearifan lokal merupakan dasar untuk pengambilan kebijakan pada level lokal di berbagai bidang, seperti kesehatan, pertanian, pendidikan, pengelolaan sumber daya alam dan kegiatan masyarakat di daerah tertentu (Soumilena, tt). Sedangkan interaksi sosial dapat diartikan sebagai hubungan timbal balik yang dilakukan oleh individu kepada individu yang lainnya. Secara umum, interaksi berarti melakukan aksi yang saling mempengaruhi satu sama lain yang dapat dijalin antar individu dengan individu, individu dengan kelompok, maupun kelopok dengan kelompok yang bersifat dinamis, memiliki intensitas waktu tertentu, dan memiliki efek tertentu (Inah, 2015).

Dengan seringnya berinteraksi, masyarakat akan saling memahami serta dapat menumbuhkan sikap toleransi. Toleransi merupakan sebuah sifat atau sikap yang mengacu pada sikap terbuka, lapang dada, suka rela. Toleran sendiri berarti bersikap menenggang (menghargai, membiarkan, membolehkan) pendirian (pendapat, pandangan, kepercayaan, kebiasaan, kelakuan, dsb.) yang berbeda atau bertentangan dengan pendirian yang kita yakini. Toleransi diartikan sebagai sikap dan tindakan yang menghargai adanya perbedaan dalam konteks agama, suku, etnis, pendapat, sikap, serta segala tindakan orang lain yang berbeda dari kita (Sufanti, Rahmawati \& Fatimah, 2015).

Sebelumnya telah ada penelitian yang membahas tentang interaksi antar-umat beragama yang dilakukan di Desa Boro, Kecamatan Selorejo, Kabupaten Blitar, karya Dewi Ratna Yulianingsih dan Muhammad Turhan Yani. Berdasarkan hasil wawancara yang dilakukan kepada 10 orang informan untuk pertanyaan mengenai pola interaksi yang terjadi di Desa boro antar umat beragama ditemukan hasil bahwa interaksi yang yang terjadi antar warga di Desa Boro menggambarkan bentuk resiprositas umum, yaitu pertukaran barang dan jasa antar umat agama tanpa menentukan kapan batas waktu pengembalian tidak ada hukum hukum yang ketat untuk memberi dan mengembalikan sumbangan, hanya moral yang mengontrol di dalamnya. Serta nilai normatife yang melatarbelakangi diantaranya yaitu nilai agama, budaya, historis, kekeluargaan dan kebersamaan.

Selain itu juga telah ada penelitian terdahulu mengenai kerukunan antar perbedaan agama, yaitu skripsi tentang kerukunan antara agama Islam, Kristen dan sunda wiwitan karya Angga Syaripudin Yusuf yang mendapatkan kesimpulan bahwa kerukunan tercipta karena saling terbuka dan menerima perbedaan yang ada dengan menanamkan sikap persaudaraan yang tinggi dan gotong royong diantara mereka, sehingga tidak membuat hubungan interaksi diantara mereka menjadi kaku dan menimbulkan sebuah konflik.

Perbedaan penelitian yang dengan penelitian terdahulu terletak pada pembahasan mengenai faktor yang melatarbelakangi berlangsungnya kegiatan atau kearifan lokal di dalam masyarakat dan pemaknaan terhadap simbol-simbol dalam kearifan lokal khususnya kegiatan Barikan yang sarat akan makna toleransi antar umat beragama yang terdapat di Desa Bororejo, Kecamatan Dadaplangu, Kabupaten Blitar.

\section{Metode}

Metode penelitian ayang digunakan dalam penelitian ini adalah menggunakan metode kualitatif, dengan cara melakukan observasi untuk mengumpulkan data mengenai kerukunan antar umat beragama berbasis kearifan lokal yang utamanya pada aspek agama dan tradisi buah hasil kearifan lokal serta bagaimana suatu kearifan lokal dapat menjadi pemersatu agama 
yang beragam dan dapat dipertahankan serta dapat diturunkan dari generasi ke generasi. Dalam hal ini digambarkan oleh tradisi Barikan, objek yang dituju dalam tradisi ini adalah seluruh masyarakat desa Dadaplangu Tradisi ini ditujukan untuk mempererat tali silaturahmi antar umat beragama di Desa Dadaplangu Kabupaten Blitar. Adapun rangkaian kegiatan Baritan dimulai dengan tahlilan atau pembacaan doa-doa yang dipimpin oleh kyai hingga selesai, kemudian dilanjutkan dengan pengambilan makanan yang telah dibawa oleh tiap-tiap masyarakan yang kemudian disusun ditengah-tengah masyarakat untuk didoakan yang nantinya makanan tersebut akan diambil secara acak atau ditukar dengan masyarakat yang lain.
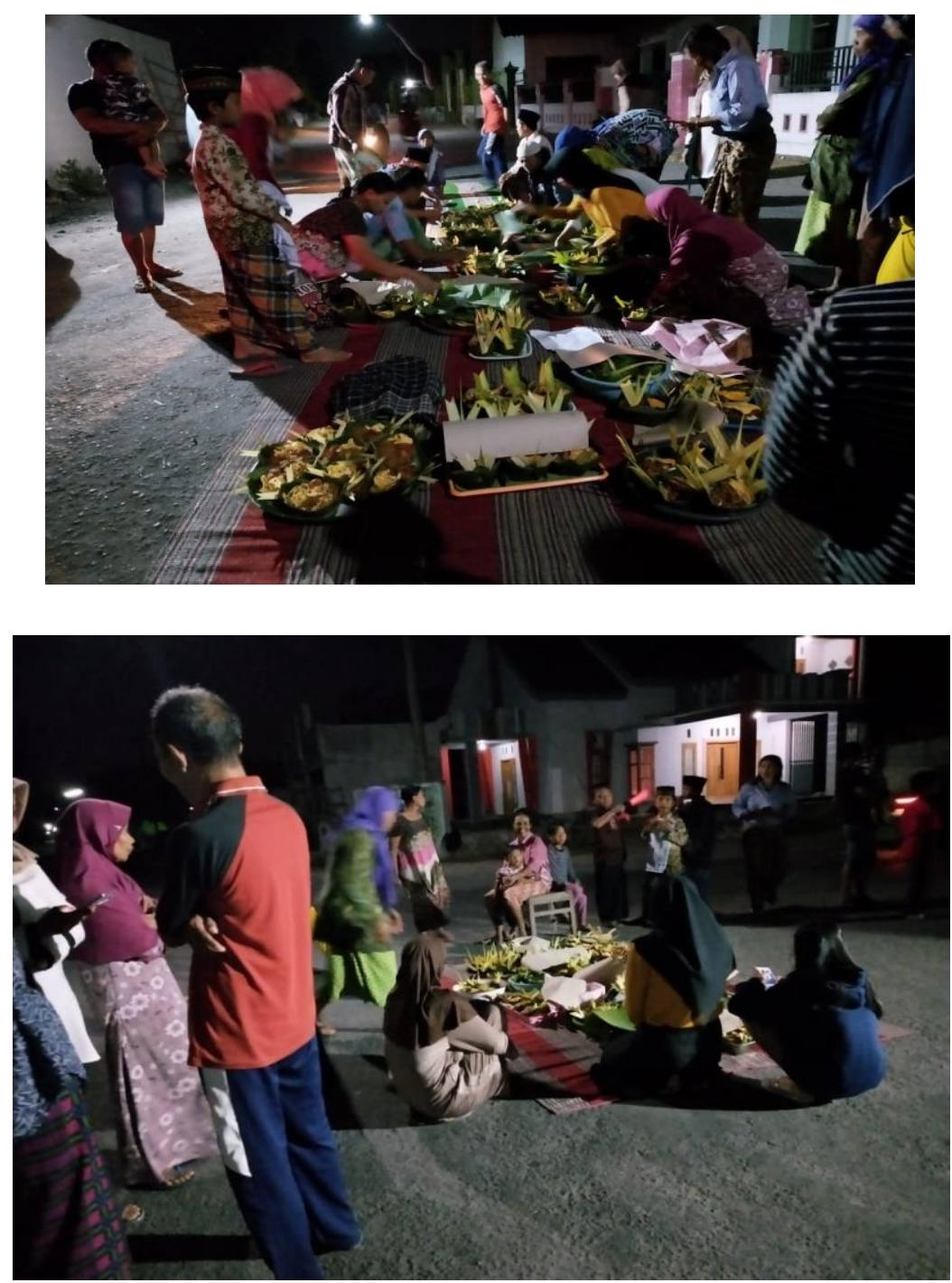

\section{Gambar 1. Potret Masyarakat Saat Menghadiri Kegiatan Barikan Di Desa Dadaplangu}

Validasi informasi dilakukan dengan cara melakukan wawancara dengan beberapa pihak terkait seperti ketua Rt daerah setempat yaitu Rt 02 Rw 06, yakni bapak Purwanto sebagai pengurus perizinan dalam penelitian sekaligus sebagai pemberi informasi ketika akan diadakannya tradisi di desa tersebut. Tokoh agama Islam yaitu bapak thohib sebagai narasumber, tokoh agama Kristen yaitu bapak Anto sebagai narasumber, kepala desa yaitu 
bapak Rokimun sebagai narasumber, perkumpulan rutin orang-orang Islam setelah sholat jum'at sebagai narasumber.

Pengumpulan data dilakukan dengan cara observasi serta menjalin komunikasi dengan beberapa pihak untuk mendapat informasi mengenai kerukunan antar umat beragama dengan mengajukan pertanyaan terhadap beberapa pihak yang berhubungan dengan penelitian ini untuk kemudian ditelaah dan dianalisis. Serangkaian proses ini dilakukan agar dapat menjamin kevalidan data yang akan dipaparkan. Tujuan dari analisis data ini adalah untuk mengetahui hal-hal ataupun aspek-aspek yang berkaitan dengan kerukunan antar umat beragama di dusun Dadaplangu serta agar pembaca bisa lebih memahami bagaimana kerukunan dapat terjalin melalui kearifan lokal yang ada ditengah-tengah keberagaman agama yang dianut serta berbagai pemaknaan terhadap simbol-simbol yang ada pada kegiatan Barikan tersebut.

Adapun proses yang dilakukan dalam penelitian tentang kerukunan antar umat beragama berbasis kearifan lokal, yakni sebagai berikut:

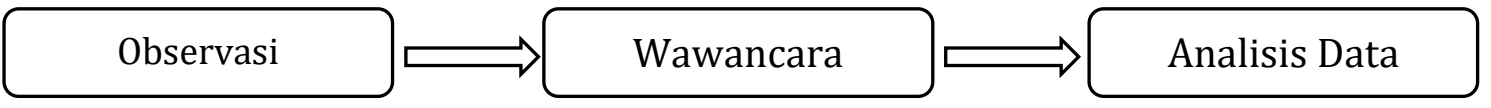

Aspek pertama merupakan tahap observasi, yaitu melihat kondisi lapangan atau kondisi lingkungan masyarakat yang ada di Dusun Bororejo, mulai dari mata pencaharian masyarakat, kegiaran yang dilakukan oleh masyarakat serta interaksi yang dilakukan oleh masyarakat satu dengan yang lain.

Aspek kedua yaitu wawancara kepada tokoh masyarakat dari perwakilan masingmasing pemeluk agama, menanyakan hal-hal tentang bagaimana toleransi antar agama yang ada di masyarakat, kemudian bagaimana tradisi barikan yang melibatkan agama-agama lain, serta menggali mengenai makna-makna yang terkandung dalam tradisi Barikan tersebut.

Aspek ketiga yaitu analisis data terhadap hasil observasi dan data wawancara dari tokoh masyarakat, dilakukan dengan mengkomparasikan data yang diperoleh dari observasi dan hasil wawancara yang telah dilakukan, kemudian dilakukan proses penarikan kesimpulan mengenai bagaimana kerukunan antar umat beragama yang ada di dusun Bororejo dengan mengaitkan fenomena sosial tersebut dengan teori dari Max Webber dan George Herbert Mead.

\section{Hasil dan Pembahasan}

Dusun Bororejo merupakan dusun yang berada di Desa Dadaplangu, Kecamatan Ponggok. Dusun yang memiliki keanekaragaman warga penduduknya, baik dalam hal perbedaan suku, agama tau sebagainya. Dusun Bororejo memiliki penduduk sejumlah 275 orang yang terdiri dari masyarakat yang memiliki latar belakang berbeda seperti halnya agama yang dianut. Dari jumlah penduduk 275 warga terdapat 41 warga yang memeluk agama Non Islam (Kristen, buddha, dll). Tempat peribadatan yang berada di dusun tersebut kebanyakan tempat peribadatan masyarakat umat Islam dengan jumlah 2 masjid serta 5 musholla / surau. Sedangkan untuk tempat peribadatan masyarakat umat Kristen, di Dusun Bororejo juga terdapat 1 Gereja yang biasa digunakan tempat beribadah oleh umat Kristen, orang-orang dari luar desa biasanya beribadah di Gereja yang ada di Dusun Bororejo tersebut. 
Dari penjelasan tersebut maka dapat diketahui bahwa Dusun Bororejo terdapat masyarakat yang memiliki latar belakang agama yang berbeda, yang membuat mereka hidup berdampingan dengan rasa toleransi yang tinggi. Bentuk interaksi sosial dalam masyarakat Dusun Bororejo berbentuk Asosiatif, dimana hubungan dalam masyarakat bersifat positif dan menghasilkan persatuan, bentuk kegiatan tersebut diantaranya biasa terlihat pada berbagai kegiatan yang dilakukan baik yang ada di dusun tersebut maupun acara pribadi dari setiap individunya.

Toleransi yang terjalin erat di dalam kehidupan masyarakat dengan adanya ritual keagamaan maupun kearifan lokal yang masih tetap dilestarikan dan ada hingga saat ini sehingga terjalin rasa kekeluargaan dinatara mereka daantaranya yaitu, Pertama, pada acara hari besar peringatan masing - masing agama (Idul Fitri, Natal, dll.), masing - masing individu akan saling menunjukkan sikap toleran dengan cara datang memenuhi undangan dan berpartisipasi dalam kegiatan agama lain serta membaur dengan mereka yang sedang memeperingati hari besar. Kedua, rasa toleransi yang di tunjukkan pada saat ada yang tertimpa duka cita, hal ini mereka tunjukkan dengan saling membantu mempersipkan acara untuk pemakaman. Untuk orang Kristen datang melayat ke rumah yang sedang berduka cita, dan membantu serta ikut menghantarkan ke tempat peristirahatan terakhir. Dan menghadiri undangan pengajian baik 7 hari, 40 hari dst, dengan cara ikut memakai baju koko dan mengenakan songkok sebagai bentuk penghormatan mereka, akan tetapi dalam acara berdoa mereka mendoakan dengan cara mereka sendiri dengan kepercayaan yang diyakini. Hal itu juga berlaku sebaliknya, masyarakat yang beragama Islam akan datang jika keluarga dari orang Kristen sedang tertimpa duka cita.

Ketiga, tradisi Barikan sebagai peringatan bersih desa atau dalam rangka peringatan 1 Suro atau 1 Muharram. Kegiatan tersebut diikuti oleh seluruh warga Dusun Bororejo, baik yang beragama Islam maupun non Islam. Hal ini dilakukan untuk menjaga kebersamaan serta rasa toleransi antar umat beragama. Seluruh masyarkat ikut serta dalam kegiatan Barikan tersebut guna mempertahankan kearifan lokal myang telah ada secara turun temurun.

Teori yang digunakan dalam penelitian ini adalah Teori Tindakan Sosial dari Max Weber dan Teori Interaksionisme Simbolik dari George Herbert Mead. Menurut Max Weber dalam karyanya tentang tindakan sosial, dijelaskan bahwa sosiologi diartikan sebagai studi tentang tindakan sosial antar hubungan sosial. Pokok dari paradigma ini "tindakan dari individu memiliki banyak arti". Maksudnya, tindakan dapat dianggap sebagai sebuah tindakan sosial apabila tindakan tersebut memiliki makna atau arti subjektif untuk dirinya sendiri dan diarahkan kepada orang lain. Sebaliknya, tindakan individu yang diarahkan kepada benda mati atau objek fisik tanpa ada hubungannya dengan tindakan orang lain dikatakan bukan termasuk tindakan sosial. paradigma ini bersifat nominalis yang mempelajari cara aktor memaknai sebuah situasi sosial mereka terhadap tindakan dan integrasi (Malik \& Nugroho , 2016).

Menurut George Herbert Mead Interaksionisme simbolik merupakan proses komunikasi antar manusia yang berlangsung melalui simbol dan pemaknaan simbol-simbol tersebut dapat berupa isyarat non-verbal dan makna sebuah pesan verbal, yang akan mempengaruhi pikiran orang ketika sedang berinteraksi. Adapun isyarat nonverbal seperti, body language atau gerak tubuh, gerak fisik, baju, status, dll, dan isyarat verbal seperti, kata-kata, suara, dll. Tiga ide dasar interaksi simbolik, antara lain: pertama, Pikiran (Mind) merupakan kemampuan menggunakan simbol yang memiliki makna sosial yang sama, dimana tiap individu mempu mengembangkan 
pikiran mereka melalui interaksi yang dijalin dengan individu lain. Kedua, Diri (Self) merupakan kemampuan untuk intropeksi diri pada individu dari penilaian sudut pandang atau pendapat orang lain. ketiga, Masyarakat (Society) merupakan media penghubung dalam hubungan sosial yang diciptakan, dibangun, dan dijalankan oleh individu dimasyarakat, dan individu tersebut terlibat dalam perilaku yang mereka pilih secara aktif dan sukarela guna mengantarkan mereka dalam proses pengambilan peran di tengah masyarakat (Siregar, 2016).

Tradisi Barikan biasanya dilakukan pada hari kamis malam jumat, masyarakat meyakini bahwa pada malam tersebut roh nenek moyang yang telah meninggal akan kembali ke rumah untuk meminta doa, dan apabila tidak didoakan, masyarakat percaya bahwa roh yang telah meninggal akan kembali ke alam kubur dengan keadaan menangis. Selain itu, pelaksaan kegiatan Barikan pada malam hari ini dilakukan karena menurut masyarakat di Desa Bororejo, malam hari merupakan waktu yang tepat untuk berdoa kepada Tuhan, karena ketika malam hari suasana yang dirasakan akan lebih hening dan sunyi sehingga doa yang dipanjatkan akan terasa lebih baik.

Dalam Tradisi Barikan tersebut masyarakat biasanya membuat tumpeng dan bubur serta jajanan pasar yang di bawa untuk acara kenduri. Hal tersebut merupakan bentuk perwujudan rasa syukur mereka dan penolak bala. Tumpeng yang dibawa berupa nasi kuning dan nasi putih beserta lauk pauk yang bisanya terdiri dari ayam, telur dan sayuran yang dibungkus dengan daun pisang. Penggunaan daun pisang dilakukan agar masakan memiliki aroma yang lebih enak, karena memiliki aroma ciri khas tersendiri yang didapat dari daun pisang tersebut. Tumpeng merupakan simbol yang digunakan untuk memuliakan arwah para leluhur mereka yang diyakini banyak bersemayam pada gunung. Lauk pauk yang ada pada tumpeng secara keseluruhan berjumlah tujuh buah, yang bermakna pitulungan (pertolongan). Ayam yang digunakan dianjurkan ayam jago, hal ini dimaksudkan agar masyarakat senantiasa menghindari sifat buruk dari ayam jago yaitu congkak, sombong, dan mau menang sendiri.

Komponen yang terdapat dalam sayur urap juga sarat akan makna, seperti toge yang bermakna tumbuh, kacang panjang bermakna pemikiran yang mengarah pada masa depan, kangkung dan bayam yang bermakna aman dan tentram atau dalam bahasa Jawa disebut dengan ayem lan tentrem, sayur-sayuran tersebut ditaburi oleh bumbu yang disebut dengan urap yang terbuat dari parutan kelapa, yang memiliki makna urip atau dalam bahasa Indonesia berarti hidup, maksudnya adalah diharapkan masyarakat mampu menghidupi keluarga, dengan begitu akan tercipta sebuah keluarga yang damai. Kemudian, telur yang disajikan biasanya diolah dengan cara direbus, yang bermakna bahwa hidup itu harus selalu direncanakan, selain itu juga memiliki makna bahwa segala sesuatu sedang dikerjakan harus sesuai dengan aturan sehingga akan mendapatkan hasil yang sempurna. Pemaknaan tersebut didapat dari proses dalam mengupas cangkang telur yang diibaratkan sebagai sebuah proses dalam merencanakan hidup.

Acara Barikan sendiri melibatkan seluruh warga masyarakat, baik yang beragama Islam maupun non Islam, yang biasa di lakukan di balai dusun atau perempatan desa dengan menggelar tikar, sehingga rasa kekeluargaan, dan kebersamaan antara sesama masyarakat dapat terjalin dengan lebih erat. Kemudian masyarakat melakukan doa bersama untuk keselamatan serta sebagai cara untuk menolak bala dengan cara membaca tahlil. Setelah acara doa bersama selesai, masyarakat akan memakan Tumpeng yang telah dibuat, mereka akan saling menukarkan masakan yang telah dibuat, hal ini memiliki makna bahwa dalam 
kehidupan bermasyarakat harus saling memahami apa yang dirasakan oleh orang lain agar dapat menciptakan sebuah iklim yang harmonis dalam kehidupan.

Bentuk dari sikap toleransi tersebut muncul dari keinginan dan kasadaran diri sendiri yang mengambarkan tidak ada perbedaan dalam sebuah masyarakat, kecuali perihal peribadatan. Mereka memelihara sikap toleransi antar sesama karena mempercayai bahwa orang terdekatlah yang akan membantu terlebih dahulu jika mendapat sebuah masalah, bukan orang yang jauh dengan kita, maka sikap baik terhadap lingkungan sekitar merupakan hal yang sangat dijunjung di Dusun Bororejo.

Selain Tradisi Barikan, di Dusun Bororejo ini juga terdapat kegiatan keagamaan, seperti tahlilan atau kenduri yang memberikan suatu dampak positif bagi masyarakat, karena masyarakat menganggap dengan adanya kegiatan tahlilan atau kenduri tersebut mampu menciptakan suatu kerukunan antar warga, selain itu kegiatan tersebut juga bertujuan untuk mendoakan arwah dari orang yang sudah meninggal, masyarakat meyakini bahwa dengan dilakukannya doa bersama-sama, maka doa akan cepat sampai kepada Yang Maha Kuasa. Kegiatan tahlilan atau kenduri sendiri identik dengan agama Islam, namun di Dusun Bororejo ini justru bukan hanya dari orang Islam saja namun dari agama lain pun juga diundang untuk ikut mendoakan arwah dari pemilik hajat. Dari hal tersebut dapat dihubungkan dengan teori Max Weber tentang tindakan sosial, dimana kegiatan dari suatu agama melibatkan keikutsertaan agama yang lain dapat menciptakan sebuah integrasi dan keharmonisan di dalam kehidupan bermasyarakat. Di dusun Bororejo ini kegiatan yang melibatkan dua agama seperti ini dilakukan sudah sejak dahulu dan tidak pertikaian atau pertentangan mengenai perbedaan agama, karena dari masing-masing pengikut agama sendiri sadar akan kegiatan yang dilaksanakan oleh suatu agama dan melibatkan agama lain bisa menciptakan kerukunan antar warga masyarakat dan juga di dusun Bororejo ini dari dulu memang toleransi antar umat beragama sangat tinggi.

Selain kegiatan yang dilakukan oleh orang Islam, kegiatan dari agama Nasrani, seperti kebaktian dan kegiatan natal. Kegiatan ini juga mengundang dan melibatkan agama Islam untuk ikut berpartisipasi didalam kegiatan mereka. Dari agama Islam pun juga menerima dengan baik undangan dari agama Nasrani. Interaksi sosial dari dua agama yang berbeda ini terjalin sangat harmonis, tindakan sosial ini bisa dilakukan oleh masyarakat dusun Bororejo semata-mata hanya untuk saling menghormati dan menghargai kegiatan dari masing-masing agama, agar kerukunan dan keharmonisan didalam hidup bermasyarakat bisa tetap terjaga hingga generasi berikutnya.

\section{Simpulan}

Dusun Bororejo merupakan sebuah daerah yang terletak di Desa Dadaplangu Kecamatan Ponggok Kabupaten Blitar. Masyarakat di Dusun Bororejo ini memiliki sikap toleransi serta rasa kekeluargaan yang cukup tinggi. Hal tersebut dapat dilihat dari adanya kegiatan yang dilakukan secara bersama-sama. Seperti kegiatan keagamaan hingga kearifan lokal yang masih dilestarikan hingga saat ini. Salah satunya adalah tradisi Barikan. Tradisi ini dilakukan sebagai wujud rasa syukur atas nikmat yang mereka miliki semasa hidup serta cara yang dilakukan oleh masyarakat untuk menolak bala. Kegiatan tersebut diikuti oleh seluruh warga Dusun Bororejo, baik yang beragama Islam maupun non Islam. Hal ini dilakukan untuk menjaga kebersamaan serta rasa toleransi antar umat beragama dan untuk mempertahankan kearifan lokal yang telah ada secara turun temurun. 
Dalam pelaksanaan tradisi ini terdapat makna-makna yang terkandung di dalamnya, mulai dari waktu pelaksanaan, makna dari rangkaian acara yang dilakukan, hingga makanan yang dibawa dalam acara tersebut. Makna-makna yang terkandung tersebut merupakan perwujudan dari nilai-nilai yang digunakan dalam kehidupan sehari-hari, pemberian makna tersebut juga bertujuan agar masyarakat senantiasa ingat akan nilai, norma, serta aturan dalam menjalani hidup secara bersama-sama, sehingga dapat menciptakan lingkungan masyarakat yang harmonis.

\section{Daftar Rujukan}

Hadi, Syamsul. (2005). Pemikiran Tentang Kerukunan Antar Umat Beragama di Indonesia. Surakarta: Universitas Negeri Surakarta. Diambil dari http://eprints.ums.ac.id/7047/1/0000030020.pdf , diakses pada tanggal 11 November 2019, pukul 04.50 WIB.

Yusuf, Angga Syaripudin. (2014). Kerukunan Umat Beragama Antara Islam, Kristen, dan Sunda Wiwitan. Jakarta: Universitas Islam Negeri Syarif Hidayatullah. Diambil dari http://repository.uinjkt.ac.id/dspace/bitstream/123456789/27292/1/ANGGA\%20SYARIPUDIN\%20 YUSUF-FITK.pdf. Diakses pada tanggal 27 Oktober 2019

Yulianingsih, Dewi Ratna \& Yani, Muhammad Turhan. (2016). Pola Interaksi Sosial Dalam Membangun Kerukunan Antar Umat Beragama Di Desa Boro Kecamatan Selorejo Kabupaten Blitar. Surabaya: Universitas Negeri Surabaya. Diambil dari https://jurnalmahasiswa.unesa.ac.id/index.php/jurnalpendidikan-kewarganegaraa/article/viewFile/15172/13738. Diakses pada tanggal 27 Oktober 2019

Soumilena Nicoll (tt). Pengertian Kearifan Lokal. diambil dari https://www.academia.edu/4145765/Pengertian_kearifan_lokal. Diakses pada tanggal 01 Desember 2019.

Sufanti, M., \& Rahmawati, F. P. (2015). Persepsi Guru Tentang Pendidikan Toleransi Kehidupan Beragama di SMA/MA Surakarta. Diakses pada tanggal 27 Oktober 2019.

Wulandriani, Irma. (2017). Filosofi Hidup dari Nasi Tumpeng Ini Akan Menginspirasimu. Diambil dari https://www.idntimes.com/life/inspiration/irma-wulandriani/filosofi-hidup-dari-nasi-tumpengc1c2/full. Diakses pada tanggal 27 Oktober 2019

Malik, A., \& Nugroho, A. D. (2016). Menuju Paradigma Penelitian Sosiologi Yang Integratif. Jurnal Sosiologi Reflektif, 10(2), 65-84. Diakses pada tanggal 27 Oktober 2019.

Inah, E. N. (2015). Peran Komunikasi dalam Interaksi Guru dan Siswa. Al-Ta'dib, 8(2), 150-167. Diakses pada tanggal 26 Oktober 2019

Siregar, N. S. S. (2016). Kajian Tentang Interaksionisme Simbolik. PERSPEKTIF, 1(2). Diakses pada tanggal 26 Oktober 2019.

Sufanti, M., Rahmawati, F. P., \& Fatimah, N. (2015). Pengembangan Bahan Ajar Apresiasi Biografi Tokoh Bermuatan Pendidikan Toleransi Kehidupan Beragama. Diakses pada tanggal 26 Oktober 2019. 